Canadian

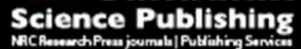

Canadian Journal of Forest Research Revue canadienne de recherche forestière

\title{
Creating boreal mixedwoods by planting spruce under aspen: successful establishment in uncertain future climates
}

\begin{tabular}{|r|l|}
\hline Journal: & Canadian Journal of Forest Research \\
\hline Manuscript ID & cjfr-2015-0440.R1 \\
\hline Manuscript Type: & Article \\
\hline Date Submitted by the Author: & 03-Feb-2016 \\
\hline Complete List of Authors: & $\begin{array}{l}\text { Kabzems, Richard; BC Ministry Forests Lands and Natural Resource } \\
\text { Operations, Northeast Region } \\
\text { Comeau, Philip; University of Alberta, Renewable Resources } \\
\text { Filipescu, Cosmin; Canadian Wood Fibre Centre, Natural Resources Canada } \\
\text { Rogers, Bruce; BC Ministry Forests, Lands and Natural Resource Operations } \\
\text { Nemec, Amanda; International Statistics and Research Corporation }\end{array}$ \\
\hline Keyword: & white spruce, aspen, boreal mixedwood, underplanting, thinning \\
\hline & \multicolumn{2}{|l}{} \\
\hline
\end{tabular}

\section{SCHOLARONE}

Manuscripts 
1 Creating boreal mixedwoods by planting spruce under aspen: successful

2 establishment in uncertain future climates

4 Richard Kabzems ${ }^{1}$, Philip G. Comeau ${ }^{2}$, Cosmin N. Filipescu ${ }^{3}$, Bruce Rogers ${ }^{4}$, Amanda

$5 \quad$ F. Linnell Nemec ${ }^{5}$

$7 \quad{ }^{1}$ British Columbia Ministry of Forests, Lands and Natural Resource Operations, Northeast

8 Region, $900017^{\text {th }}$ Street, Dawson British Columbia, B.C., V1G 4A4

9 Corresponding author (e-mail: Richard.Kabzems @ gov.bc.ca)

$10{ }^{2}$ Centre for Enhanced Forest Management, Department of Renewable Resources, 751 General

11 Services Building, University of Alberta, Edmonton, Alberta, T6G 2H1 (email:

12 pcomeau@ualberta.ca )

$13{ }^{3}$ Canadian Forest Service, 506 Burnside Road West, Victoria B.C. V8Z 1M5 (email

14 cosmin.filipescu@canada.ca )

$15{ }^{4}$ British Columbia Ministry of Forests, Lands and Natural Resource Operations5th Floor - 1044

16 Fifth Ave., Prince George, B.C., V2L 5G4 (email bruce.rogers@gov.bc.ca )

$17{ }^{5}$ International Statistics \& Research Corporation, P.O. Box 39, Brentwood Bay, B.C. V8M 1R3

18 (email afln@isr.bc.ca)

19 


\section{Abstract}

22 Planting white spruce under established aspen stands has substantial potential for regenerating

23 mixedwood ecosystems in the western Canadian boreal forest. The presence of an aspen

24 overstory serves to ameliorate frost and winter injury problems and suppresses understory

25 vegetation that may compete with white spruce. Under future climatic regimes with more

26 frequent and severe drought episodes, underplanting may be a cost-effective strategy for

27 lowering the risk of mortality in mixedwood regeneration. We examine the growth of white

28 spruce during the first 18 years after being planted beneath a 39 year old stand of trembling

29 aspen. Treatments included thinning from over 6000 stems ha $^{-1}$ to 3000, 2000 and 1000 stems

$30 \mathrm{ha}^{-1}$, and fertilization. Initial stimulation of understory vegetation by fertilization had no

31 measureable effect on spruce heights or diameters at year 18. Aspen thinning treatments did not

32 have a significant effect on spruce height growth rates after spruce crowns had emerged above

33 the understory shrub layer due to rapid aspen basal area increases post-thinning. Small, but

34 significant increases for spruce height and diameter were present in the 1000 and 2000 stem ha $^{-1}$

35 aspen thinnings. A much wider range of aspen stand conditions may be suitable for planting

36 spruce to create mixedwood ecosystems than has been previously considered.

38 Keywords: white spruce, aspen, boreal mixedwood, underplanting, thinning 


\section{Introduction}

42 The underplanting of mature (40 - 60 year old) trembling aspen (Populus tremuloides

43 Michx.) stands with white spruce (Picea glauca (Moench) Voss) has been recommended as a

44 feasible mixedwood management silviculture practice that would result in stands similar in

45 structure to many natural mixedwood stands (DeLong 2000, Lieffers and Grover 2004).

46 Experimental underplantings of aspen stands with white spruce were first established in the

47 western Canadian boreal forest in the 1960's (Duffy 1963), and there was a resurgence of interest

48 in the topic in the 1990's (Lieffers and Grover 2004). Reports of good survival and early growth

49 of underplanted spruce in various settings (Stewart et al. 2000; Comeau et al. 2004, 2009)

50 support the application of this technique in boreal mixedwoods.

51 Moisture deficits or temperature induced drought stress have defined the more recent

52 boundaries between white spruce forest ecosystems and grasslands (Chhin and Wang 2008).

53 Northern expansion of grassland climates and declines in boreal forest ecosystems have been

54 predicted under several climate change scenarios in western North America (Mbogga et al. 2010,

55 Rehfeldt et al. 2012). Western Canadian boreal forests may be particularly vulnerable to the

56 combined effects of multi-year droughts (Wang et al. 2014), drought induced mortality of

57 susceptible tree species (Hogg 2001, Hogg and Bernier 2005), increased fire frequency

58 (Haughian et al. 2012, de Groot et al. 2013), and human caused disturbances (Nlungu-Kweta et

59 al.. 2014). Increasing fire frequency could change the dynamics of conifer recruitment under

60 aspen stands (Nlungu-Kweta et al. 2014). With projected changes in climate, it is likely that

61 dramatic and unexpected changes may occur in boreal ecosystems (Price et al. 2013). Some

62 modelling studies have suggested that the current aspen parkland ecosystems might be replaced 
63 by grasslands, and that upland mixedwood forests might be replaced by aspen dominated types

64 (Hogg and Bernier 2005, Schneider et al. 2009).

Boreal forests in north-eastern British Columbia have historic (1961-1990) annual

66 climatic moisture deficits ranging from $172 \mathrm{~mm}$ in Dawson Creek to $122 \mathrm{~mm}$ in Fort Nelson,

67 which are projected to increase by $38 \mathrm{~mm}$ in Dawson Creek, and $29 \mathrm{~mm}$ in Fort Nelson by the

68 2050's (Wang et al. 2012, http://climatemodels.forestry.ubc.ca/climatebc/downloads). With a

69 lesser degree of change in climate, modification of current stand level practices may be effective

70 in maintaining current forests at the level of stands and landscapes. The projected increases of

71 mean annual temperature in north-eastern BC ( $\underline{\text { http://www.pacificclimate.org/news-and- }}$

72 events/news/2013/regional-climate-summaries) of over $3.2^{\circ} \mathrm{C}$ would reach the threshold of

73 conditions where 'novel silviculture', or a wider array of silviculture practices and sources of

74 knowledge, needs to be considered to regenerate desired future forests (Park et al. 2014).

75 Changing climates may favour strategies of establishing regeneration under an existing forest

76 cover (Park et al. 2014), adding new dimensions to the traditional silvicultural view of how

77 overstory trees modify the environment of seedlings and saplings (Pommerening and Murphy

78 2004), in particular the balance between water conservation, evapotranspiration and consumption

79 by the mature forest.

80 In boreal ecosystems conifer regeneration generally occurs long after the initial

81 disturbance and often continues throughout the life of the stand (Bergeron et al. 2014).

82 Underplanting of conifers is a management option to maintain this feature in the boreal forests

83 which develop under future climates, particularly if spruce seed sources are decreased on the

84 landscape. When spruce seedlings are planted under 40 to 60 year old aspen canopies, they are

85 less vulnerable to stochastic factors such as weather and the combinations of seed source, 
86 seedbed, and microclimate required for successful white spruce natural regeneration summarized 87 by Gartner et al. (2011).

Compared to a clearcut, the growing environment under a mature aspen canopy has

89 reduced risk for growing season frost (Groot and Carlson 1996, Pritchard and Comeau 2004),

90 and white pine weevil (Pissodes strobi Peck) incidence (Taylor et al. 1996). Moisture conditions

91 for underplanted spruce are also expected to be superior due to the greater relative humidity and

92 lower temperature (Marsden et al. 1996) and improved rooting zone soil moisture conditions

93 created by redistribution of soil water by the aspen root system (Brown et al. 2014).

94 This study builds on the previous work of Comeau et al. (2004, 2009) describing the

95 effects of fertilization and thinning treatments carried out in aspen stands on the initial growth of

96 white spruce planted beneath them. Fertilization stimulated understory vegetation and did not

97 benefit the planted spruce (Comeau et al. 2004). Thinning to 2000 and 1000 stems ha $^{-1}$ did not

98 increase the light reaching seedlings during the growing season when spruce crowns were

99 primarily below the $1.5 \mathrm{~m}$ tall shrub layer (Comeau et al. 2009). However, there were small,

100 statistically significant increases in spruce height and diameter for the 1000 and $2000 \mathrm{stems} \mathrm{ha}^{-1}$

101 thinnings compared to the control and 3000 stems ha $^{-1}$ thinning (Comeau et al. 2004, 2009). The

102 significant differences in spruce growth between aspen treatments are likely due to differences in

103 seasonal light transmission; that is, when deciduous trees and understory plants are not fully

104 leafed out (Constabel and Lieffers 1996, Chen et al. 1997, Prevost and Pothier 2003), the

105 conifers are photosynthetically active (Man and Lieffers 1997). In previous studies,

106 photosynthetically active radiation levels declined rapidly between May 15 and June 8 as

107 deciduous trees and shrubs leafed out (Comeau et al. 2009) and increased rapidly after August 30

108 with leaf senescence measured at $1.5 \mathrm{~m}$ above ground level. At the end of September light levels 
109 in the $2000 \mathrm{st} \mathrm{ha}^{-1}$ treatment were $40 \%$ of the open sky values, while control and $3000 \mathrm{st} \mathrm{ha}^{-1}$

110 treatments had only $30 \%$ of open sky values (Comeau et al. 2009).

111 Continued examination of long term experiments allows for the testing of new

112 hypotheses, for example, the environment under aspen stands would be more favourable than a

113 conventional clearcut for survival and growth of planted spruce under changing future climates.

114 We also need to consider the validity of early experimental results as the influence of different

115 ecosystem components, such as the shrub layer, varies with continued height growth of spruce.

116 This paper presents 18 year results from two studies conducted to examine the growth of

117 spruce following underplanting. The first study (Sierra Road, near Fort Nelson, British

118 Columbia) involved underplanting spruce in plots that were previously established for a factorial

119 experiment designed to examine the effects of thinning and fertilization on a 39 year old

120 trembling aspen stand. We also present results from analysis of data from a second study

121 established in 1993 by DeLong (2000) near Dawson Creek, British Columbia, where spruce were

122 underplanted in two untended stands that were approximately 45 years old. Data from both

123 studies are used to examine height and diameter growth of underplanted spruce, and to determine

124 if survival, height and diameter growth during the first 18 years is similar in untended aspen

125 stands at the two locations.

126 Hypotheses being investigated are:

127 i) Thinning aspen improves conditions for growth of planted white spruce

128 ii) Fertilizing aspen impedes establishment of white spruce

129 iii) Underplanted spruce growth rates increase when the spruce canopy layer becomes

130 taller than the $1.5 \mathrm{~m}$ shrub layer. 


\section{Materials and Methods}

\section{Sierra Road study}

134 The Sierra Road experiment was established in the fall of 1991 in a 39 year-old aspen

135 stand located $85 \mathrm{~km}$ east of Fort Nelson, B.C. $\left(58^{\circ} 45^{\prime} \mathrm{N}, 121^{\circ} 37^{\prime} \mathrm{W}\right)$. The site was classified

136 as a Trembling aspen - Green alder - Highbush cranberry site series (BWBSmk/101\$6B.1,

137 DeLong et al. 2011) with a mesic soil moisture regime and medium nutrient regime on loam

138 texture soils with gently undulating topography. The original intent was to examine the effects

139 of spacing and fertilization on aspen growth. The experiment involved 4 levels of spacing: 1)

140 untreated (basal area $35.2 \mathrm{~m}^{2} \mathrm{ha}^{-1}$, between 6000 and $8000 \mathrm{stems} \cdot \mathrm{ha}^{-1}$ ); 2) $3000 \mathrm{stems} \cdot \mathrm{ha}^{-1}$ (basal

141 area $27.7 \mathrm{~m}^{2} \mathrm{ha}^{-1}, 1.83 \mathrm{~m}$ square spacing); 3) $2000 \mathrm{stems} \cdot \mathrm{ha}^{-1}$ (basal area $19.9 \mathrm{~m}^{2} \mathrm{ha}^{-1}, 2.24 \mathrm{~m}$

142 square spacing); and 4) $1000 \mathrm{stems} \cdot \mathrm{ha}^{-1}$ (basal area $12.5 \mathrm{~m}^{2} \mathrm{ha}^{-1}, 3.16 \mathrm{~m}$ square spacing). Spacing

143 treatments were completed during fall of 1991 using chainsaws, with slash left untreated on the

144 ground. The four levels of fertilization used in this study were: 1) untreated; 2) $100 \mathrm{~kg} \cdot \mathrm{ha}^{-1} \mathrm{of} \mathrm{N}^{\mathrm{N}}$

145 applied as ammonium nitrate; 3) $200 \mathrm{~kg} \cdot \mathrm{ha}^{-1}$ of $\mathrm{N}$ applied as ammonium nitrate; and, 4) a

146 complete fertilizer mix comprising $200 \mathrm{~kg} \cdot \mathrm{ha}^{-1}$ of $\mathrm{N}$ (ammonium nitrate) plus $100 \mathrm{~kg} \cdot \mathrm{ha}^{-1}$

147 phosphorus, $100 \mathrm{~kg} \cdot \mathrm{ha}^{-1}$ potassium, $25 \mathrm{~kg} \cdot \mathrm{ha}^{-1}$ magnesium, $50 \mathrm{~kg} \cdot \mathrm{ha}^{-1}$ sulphur, and $1.5 \mathrm{~kg} \cdot \mathrm{ha}^{-1}$

148 boron. Fertilizer was applied in the selected plots by hand during June of 1994. A randomized

149 block design was used, with three separate blocks each containing sixteen $40 \mathrm{~m}$ by $40 \mathrm{~m}$ plots.

150 The original plan was to apply each of the 16 thinning-fertilizer combinations to one plot per

151 block; however, errors during treatment application resulted in some treatments being repeated

152 more than once in certain blocks and some treatments not occurring in certain blocks.

In 1996, each plot was planted in early July with container (2+0 415B Styroblock) grown

154 white spruce seedlings at a density of $1300 \mathrm{stems} \cdot \mathrm{ha}^{-1}$ (2.8 $\mathrm{m}$ square spacing). Seedlings were 
155 planted in a regular pattern with up to $0.5 \mathrm{~m}$ variation allowed in spacing if required to avoid

156 debris piles or living aspen stems. The central $20 \mathrm{~m}$ by $20 \mathrm{~m}$ area in each plot was chosen as the

157 assessment area and 20 spruce seedlings within the plot were tagged for repeated assessment.

158 Height and root collar diameter were measured in 1999, 2002, and 2007. In 2007 spruce

159 measurements were limited to two fertilizer treatments (control and nitrogen plus

160 micronutrients). Height and diameter at $1.3 \mathrm{~m}(\mathrm{dbh})$ were measured for all treatments in 2014.

161 Damage resulting from hare browsing or other factors was noted at the time of measurement.

162 Between 2007 and 2014 three plots located in two blocks at Sierra Road were lost as the result of

163 road construction or oil and gas exploration activities.

164 All the live aspen taller than $1.5 \mathrm{~m}$ in 2003 and 2014 were measured for dbh within the 165 central $20 \mathrm{~m} \times 20 \mathrm{~m}\left(400 \mathrm{~m}^{2}\right)$ permanent sample plot.

166

174 regimes, classified as Trembling aspen - Prickly rose - Creamy peavine site series (BWBSmw

175 101\$6B.1, DeLong et al. 2011). In each stand, seedlings were planted in 1993, with planting

176 locations for each tree selected to be as far from adjacent aspen stems as possible, while trying to 
177 achieve an overall planting density of $1120 \mathrm{stems} \cdot \mathrm{ha}^{-1}$. Shrub and herbaceous vegetation were 178 removed by clipping within a $1 \mathrm{~m}$ radius surrounding each planted seedling immediately prior to 179 planting. Height, root collar diameter and dbh (when $1.3 \mathrm{~m}$ height was achieved) were measured 180 regularly between 1993 and 2015 (year 18 post planting). At year 15, circular permanent sample 181 plots were established within the original rectangular plots, which reduced the number of trees

182 being measured. Survival is reported on all trees monitored from planting to year 15 at the 183 Dawson Creek site. Damage resulting from hare browsing or other factors was noted at the time 184 of measurement.

\section{Data analysis}

Data analysis was completed using SAS (SAS Institute Inc., Cary, North Carolina).

187 An ANOVA of the growth performance of planted spruce was carried out by fitting the 188 following mixed-effects model:

$$
\text { (1) } y_{i j k l m}=\beta_{i}+\mu+\alpha \times h_{i j k l m}+\mathrm{S}_{j}+\mathrm{F}_{k}+\mathrm{SF}_{j k}+\delta_{l(i j k)}+\varepsilon_{m(i j k l)}
$$

190 where $i, j, k, l$, and $m$ denote respectively block, spacing level, fertilizer level, plot, and tree; $y_{i j k l m}$ 191 is the 2014 (18 years post planting) growth variable of interest (height, DBH, etc.) and $h_{i j k l m}$ is 192 the corresponding height in 1997 (as measured in 1999); $\mu$ is the overall (fixed) mean; and $\alpha \times$ $193 h_{i j k l m}$ is the fixed effect of planting height, which was included to adjust for initial differences 194 unrelated to treatment; $\mathrm{S}_{j}, \mathrm{~F}_{k}$, and $\mathrm{SF}_{j k}$ are respectively the fixed main and interactive effects of

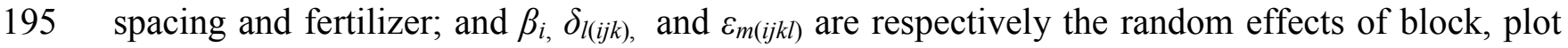
196 (block $\times$ spacing $\times$ fertilizer interaction), and tree. All random effects were assumed to be

197 independent and normally distributed, with mean 0 and respective variances $\sigma_{\beta}^{2}, \sigma_{\delta}^{2}$, and $\sigma^{2}$. 198 Model parameters were estimated by the restricted maximum likelihood method (REML method, 199 PROC MIXED). 
The statistical significance of the main and interactive effects of spacing and fertilizer

201 were tested by pseudo-F tests with denominator degrees of freedom approximated by the

202 Satterthwaite method. Adjusted least-squares means (assuming a common planting height of 27

$203 \mathrm{~cm}$ ) were calculated for the main and interactive effects of spacing and fertilizer. Mean

204 differences, estimated standard errors, and unadjusted p-values based on the corresponding t-

205 tests (Bonferroni-adjusted p-value $=6 \times$ unadjusted p-value) were calculated for all pairs of

206 spacing levels. Fertilizer differences were found to be small and not statistically significant, and

207 are not reported. Differences between the mean growth of spruce underplanted in control plots

208 (no spacing or fertilization) at the Sierra Road site (Fort Nelson) and the corresponding growth at

209 the Dawson Creek site were tested by applying a t- test (with degrees of freedom approximated

210 by the Satterthwaite method) to the respective least-squares (year 18) means.

\section{Results}

213 Survival of white spruce at Sierra Road 18 years after planting was between 95 and 99\%

214 (Table 1) and 95 to $97 \%$ at year 15 in Dawson Creek. Incidence of damaging agents was very 215 low in at both sites (data not shown).

216 Results of the ANOVA of fertilization and aspen spacing effects on spruce growth (using

217 height at planting as a covariate) are summarised in Table 2. Aspen spacing had a significant 218 effect on spruce height, diameter at $1.3 \mathrm{~m}$, and height/diameter ratio (Table 2a). Spruce height at 219 age 18 decreased with increasing aspen density (Figure 1). It was lowest for the control and the 220 
223 Figure 1. Mean spruce height (_tstandard error) in 2014 for the aspen thinning treatments at 224 Sierra Road.

225

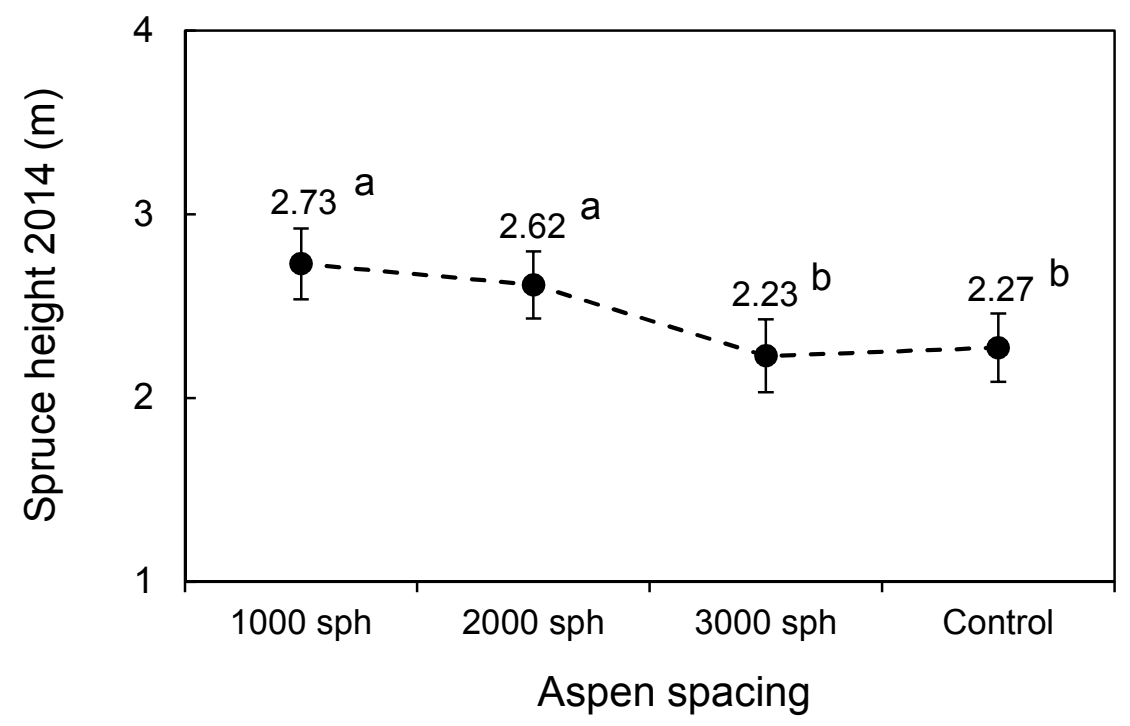

227 treatments, with no significant difference between the two treatments, and greatest for the 1000

$228 \mathrm{st} \mathrm{ha}^{-1}$ and $2000 \mathrm{st} \mathrm{ha}^{-1}$ treatments, again with no significant difference between those two

229 treatments. Spruce diameter increased with thinning (Figure 2) with significantly larger

230 diameters for the $1000 \mathrm{st} \mathrm{ha}^{-1}$ and $2000 \mathrm{st} \mathrm{ha}^{-1}$ treatments compared to the control and $3000 \mathrm{st} \mathrm{ha}^{-}$

$231{ }^{1}$ treatments (resulting, respectively, in estimated gains of $64 \pm 26$ (mean \pm standard error) $\mathrm{mm}$

232 and $45 \pm 24 \mathrm{~mm}$ relative to the control, and $75 \pm 27 \mathrm{~mm}$ and $56 \pm 26 \mathrm{~mm}$ relative to the $3000 \mathrm{st}$

$233 \mathrm{ha}^{-1}$ treatment). The spruce height/DBH was significantly lower in the $1000 \mathrm{st} \mathrm{ha}^{-1}$ and $2000 \mathrm{st}$

$234 \mathrm{ha}^{-1}$ treatments $\left(-36 \pm 12\right.$ and $-25 \pm 12$, respectively; Figure 3), compared to the $3000 \mathrm{st} \mathrm{ha}^{-1}$

235 treatment, but there was no significant difference when compared with the control.

236 Spacing had only a marginally significant effect $(\mathrm{p}=0.11)$ on mean spruce height

237 increment between 2002 and 2014 (Table 2b, Figure 4); the largest differences were between the $2381000 \mathrm{st} \mathrm{ha}^{-1}$ and $3000 \mathrm{st} \mathrm{ha}^{-1}$ treatments $(3 \pm 2 \mathrm{~cm} /$ year, $\mathrm{p}=0.04)$ and between the $1000 \mathrm{st} \mathrm{ha}^{-1}$ 
239 Figure 2. Mean spruce breast height $(1.3 \mathrm{~m})$ diameter ( 240 thinning treatments at Sierra Road.

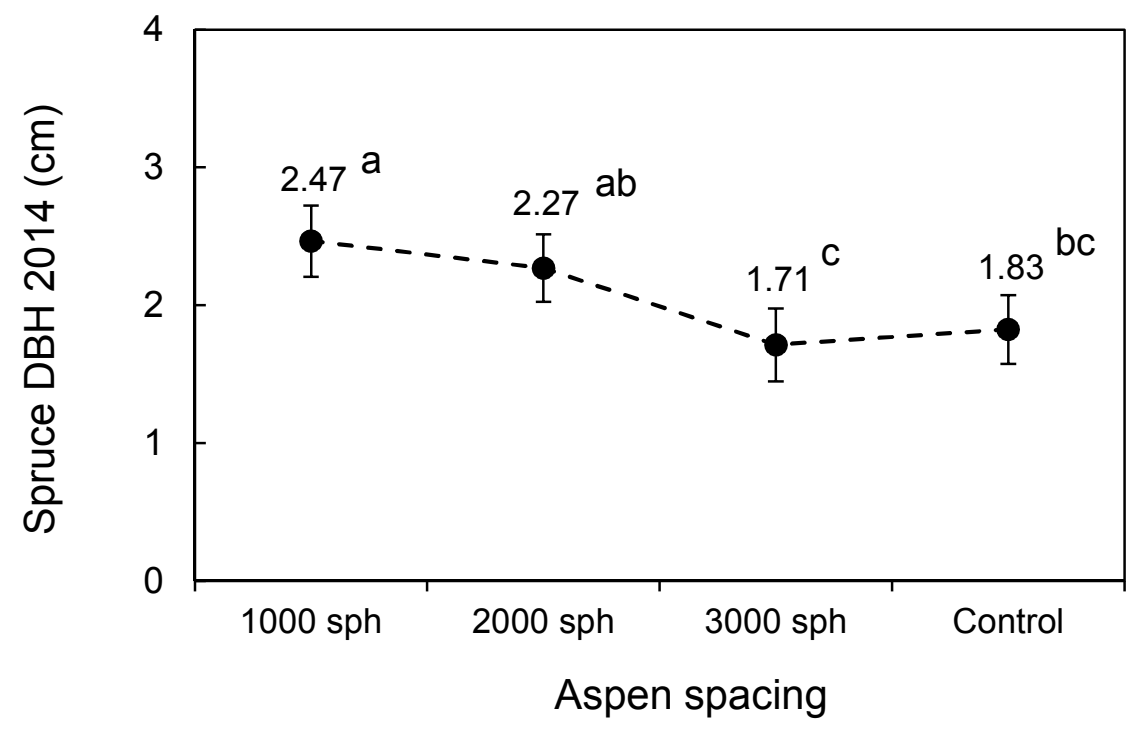

242 Figure 3. Spruce height/dbh ( \pm standard error) in 2014 for the aspen thinning treatments at Sierra 243 Road.

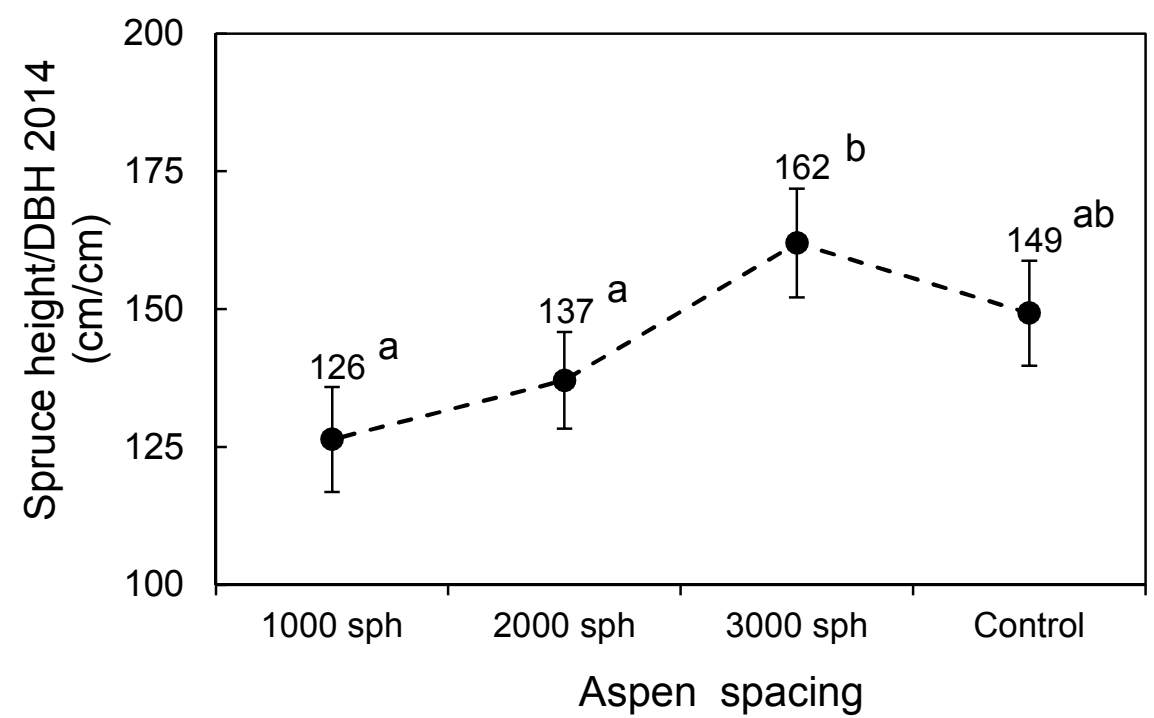

245 treatment and the control $(3 \pm 1 \mathrm{~cm} /$ year, $\mathrm{p}=0.06)$. The aspen spacing treatment had no 246 significant effect (Table 2b) on mean spruce height increment between 2007 and 2014. There

247 was a significant difference in root collar diameter growth for the spacing treatments between 2482002 and 2007(Table 2b), the largest differences were between the $1000 \mathrm{st} \mathrm{ha}^{-1}$ and $3000 \mathrm{st} \mathrm{ha}^{-1}$ 
249 treatments $(5 \pm 2 \mathrm{~mm} /$ year, $\mathrm{p}=0.03)$. There were no significant difference $(\mathrm{p}=0.45)$ between the 250 control and $3000 \mathrm{st} \mathrm{ha}^{-1}$ treatments or the 1000 and $2000 \mathrm{st} \mathrm{ha}^{-1}$ treatments $(\mathrm{p}=0.88)$ for root 251 collar diameter growth between 2002 and 2007. Root collar diameter measures were not done in 252 2014, and only 48 spruce were measured for DBH in 2007. As a result, differences between 253 aspen thinning treatments for spruce root collar diameter or DBH increments from 2007-2014 254 could not be tested.

255 Figure 4. Mean spruce height increment 2002 - 2014 ( \pm standard error) in 2014 for the aspen 256 thinning treatments at Sierra Road.

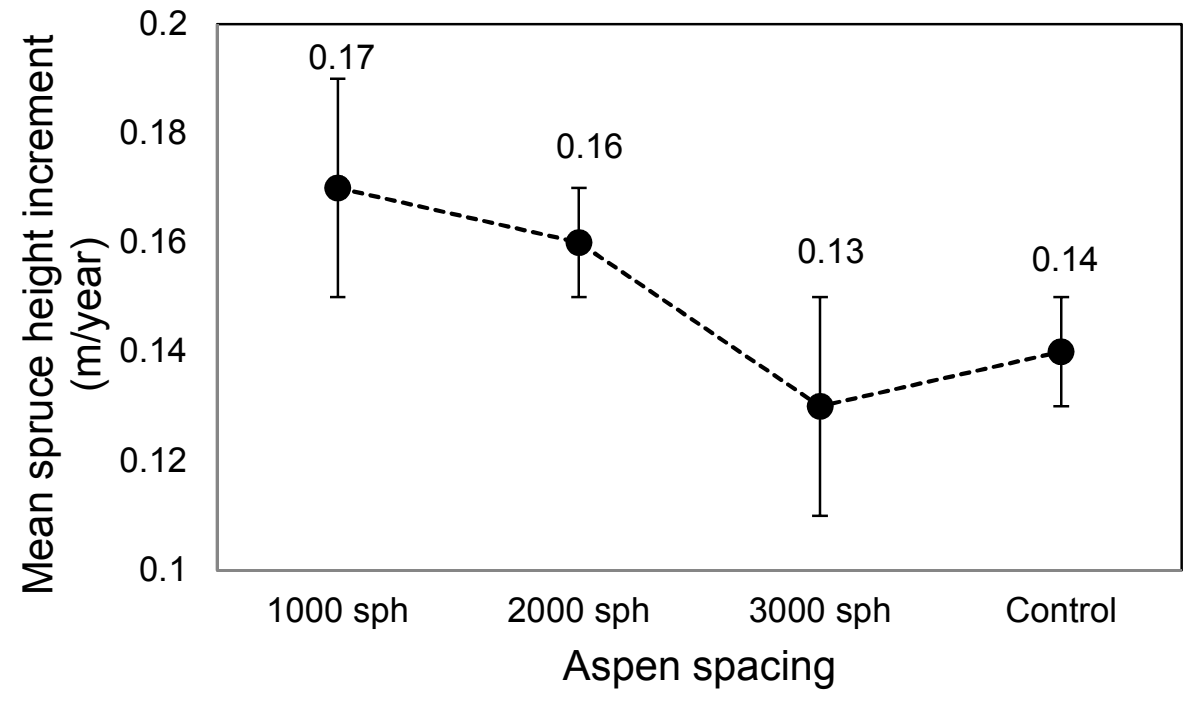

259 Mean spruce heights at age 18 for the control aspen treatment at the Sierra Road and 260 Dawson Creek sites, $2.29 \pm 0.21 \mathrm{~m}$ and $2.22 \pm 0.08 \mathrm{~m}$, respectively, were not significantly 261 different $(\mathrm{p}=0.78)$. Likewise, the estimated mean spruce diameters, for the control aspen 262 treatment, $1.82 \pm 0.28 \mathrm{~cm}$ and $1.69 \pm 0.11 \mathrm{~cm}$, did not differ significantly $(\mathrm{p}=0.66)$ between the 263 two sites. Height to dbh was 149 at Sierra Road and 145 at Dawson Creek.

264 During the 1993 to 2014 measurement period, aspen stand mean density declined at the 265 Sierra Road site (Table 3) and basal area increased for all aspen spacing treatments. Between 
2661992 and 2003 the $3000 \mathrm{st} \mathrm{ha}^{-1}$ treatment had increased basal area to $36.3 \mathrm{~m}^{2} \mathrm{ha}^{-1}$, which was 267 very similar to the control at $38.5 \mathrm{~m}^{2} \mathrm{ha}^{-1}$ (Table 3). By 2014 the $3000 \mathrm{st} \mathrm{ha}^{-1}$ treatment had a 268 greater basal area than the control. The $2000 \mathrm{st} \mathrm{ha}^{-1}$ treatment had the greatest basal area growth 269 between 2003-2014, and 2014 basal area for this treatment was only $8.5 \%$ less than the control 270 (Table 3).

271 Discussion

272 At the Sierra Road site, white spruce had good survival and acceptable early growth rates.

273 There was no detectable difference in spruce survival between the different aspen densities at

274 Sierra Road, and no apparent difference in spruce survival between Fort Nelson and Dawson

275 Creek. These rates compare favorably with the 20 year survival rates from Alberta

276 underplanting done in the 1960's, which ranged from 28 to 83\% (unpublished data 1983,

277 Forestry Canada Project A.83 - as cited by DeLong 2000) and five year survival of trees planted

278 on scarified strips under aspen in Manitoba which averaged 73\% (Dyck 1994). The greatest

279 occurrence of hare damage was observed in year 5 at Sierra Road (Comeau et al. 2004) and at a

280 similar age at the Dawson Creek sites. The occurrence of other damaging agents was minor at

281 both Sierra Road and Dawson Creek in the first 18 years after planting, consistent with the

282 reduced incidence of damaging agents such as white pine weevil (Taylor et al. 1996) in boreal

283 mixedwoods.

$284 \quad$ Fertilization of the aspen stand did not have significant positive or negative consequences

285 for white spruce growth eighteen years after planting. Initially, fertilization stimulated growth of 286 understory vegetation and increased the Leaf Area Index (LAI) of the understory vegetation 287 layers (Comeau et al. 2004). 
The differences in mean height between treatments were statistically significant but

289 relatively small during the measurement period, since the change in light levels created by the

290 aspen thinning treatments were limited to the beginning and end of the growing season (Comeau

291 et al 2009). At the Sierra Road site the differences were $10 \mathrm{~cm}$ at year 5 (Comeau et al. 2004),

292 approximately $30 \mathrm{~cm}$ in year 10 (Comeau et al. 2009), and approximately $45 \mathrm{~cm}$ year 18 ,

293 representing $20 \%$ greater height in the $1000 \mathrm{st} \mathrm{ha}^{-1}$ treatment compared to the control. The 1000

294 and $2000 \mathrm{st} \mathrm{ha}^{-1}$ treatments had greater diameters and lower height/diameter ratios than the

295 control and $3000 \mathrm{st} \mathrm{ha}^{-1}$ treatments. These results reflect the fact that diameter growth of

296 conifers is more sensitive to competition than height growth (Lanner 1985). Viburnum and Rosa,

297 which dominated this study site, do not form the extremely light limiting shrub layers found in

298 other aspen ecosystems, e.g. those comprising Corylus and Acer in central Manitoba and eastern

299 Canadian boreal forests (Waldron 1959, Trottier 1981, Kemball et al. 2005). There may be

300 additional interactions between spruce seedlings and shrubs below ground which this study

301 design was unable to examine (Montgomery et al. 2010).

It was anticipated that there would be a clear acceleration of spruce growth with better

303 light availability in the more open aspen spacings, which should have enabled growth through

304 the understory shrub layer into an even better light environment. There was no evidence that

305 spruce in the less dense aspen environments had a significantly more rapid growth rate as they

306 grew above the understory shrub layer. There were no significant differences in spruce height

307 growth rates between the four aspen treatments in the more recent 2007 - 2014 measurement

308 interval. The relationship between the different aspen thinning treatments for root collar

309 diameter growth 2002 - 2007 was similar to the relationship for spruce DBH in 2014, where it

310 was lowest for the control and the $3000 \mathrm{st} \mathrm{ha}^{-1}$ treatments, with no significant difference between 
311 the two treatments, and greatest for the $1000 \mathrm{st} \mathrm{ha}^{-1}$ and $2000 \mathrm{st} \mathrm{ha}^{-1}$ treatments, again with no 312 significant difference between those two treatments.

313 Differences in aspen basal area between the treatments were much smaller in 2014 than

314 when the experiment was established in 1992 (Table 3), as the retained aspen responded rapidly

315 to the available growing space on this productive site. As the planted spruce were emerging

316 through the shrub canopy, ten years after the aspen spacing took place, the initial differences in

317 basal area and aspen canopy light environments had decreased. The benefits to the spruce

318 portion of the mixedwood stand from the aspen thinning treatments were small but statistically

319 significant. With a commercial thinning of the aspen, there would be improved growing

320 conditions for both species. In the absence of economically viable aspen thinning treatments,

321 these results indicate that spruce could be successfully planted under a relatively wide range of 322 aspen basal area conditions, with appropriately lower expectations for initial spruce growth rates.

323 The growing environment in a clearcut has greater and more variable air temperatures

324 throughout the growing season, and greater soil temperatures, than under an aspen canopy

325 (Carlson and Groot 1997). At the Sierra Road site, there were dramatic differences in growing

326 degree days (GDD) between the aspen stands (GDD 699 - 754) and an adjacent open area (GDD

327 1067) (Comeau et al. 2009). Differences between the different aspen densities in their associated

328 air temperatures and GDD were relatively small. Based on the Sierra Road site, a range of aspen

329 densities greater than $1000 \mathrm{st} \mathrm{ha}^{-1}$ at age 40 or a minimum basal area of $12 \mathrm{~m}^{2} \mathrm{ha}^{-1}$ could provide

330 an ameliorated environment for the establishment of spruce under the more variable and stressful

331 climates predicted for the future.

332 Underplanted white spruce have lower rates of height and diameter growth than spruce

333 grown in clearcuts. The total heights of underplanted spruce at the Sierra Road site ranged from 
3342.7 to $2.3 \mathrm{~m}$ compared to $3.3 \mathrm{~m}$ tall white spruce with a ht/dbh of 117 in a fifteen year old

335 clearcut near Fort Nelson which were mixed with aspen (unpublished data from remeasurement

336 of Kabzems et al. 2011). In the same experiment, the white spruce in a vegetation control

337 treatment (glyphosate) averaged $4.3 \mathrm{~m}$ in height with a ht/dbh of 85 (unpublished data from 338 remeasurement of Kabzems et al. 2011).

The goal of underplanting is to set the stage for a harvest of the mature aspen canopy in

340 the future, while retaining sufficient spruce to create an additional harvest opportunity. The

341 underplanted spruce at the Sierra Road site is predicted to reach a sufficient height (4 m, Johnson

342 1986) within 30 years of planting, to stay above post harvest aspen regeneration. A height to

343 diameter ratio less than 100 would reduce windthrow risk (Navratil 1996) after aspen harvest in

344 the application of an understory protection management approach (Grover et al. 2014).

345 However, the design of leave strips to provide adequate wind protection is far more critical to

346 retaining spruce post harvest (MacIsaac and Krygier 2009).

Underplanting is a technique which is consistent with recommended forest management

348 options for adapting to climate change. Regeneration of white spruce in a less stressful

349 environment will increase the chance of subsequent regeneration success in managed forests

350 (Johnston et al. 2009). The identification of novel silviculture applications will enhance adaptive

351 capacity (Johnston et al. 2009). The establishment of mixed species and uneven-aged stands

352 enhances ecosystem resiliency (O’Hara and Ramage 2013). Aspen canopies facilitate building

353 of snow pack and greater water yield (LaMalfa and Ryle 2008) which conserves snow and soil

354 moisture in the drier environments of the western Canadian boreal forest (Wang et al. 2014).

355 Given the current future climate projections, these positive hydrologic features of aspen

356 dominated stands become more valued for the successful establishment of spruce. 
Our results provide encouraging evidence for operational implementation of planting

358 spruce under aspen. In this regard, we recommend further research on a number of topics to

359 support successful adoption of this novel management practice. There needs to be careful

360 examination of implications for future timber supply through growth and yield modelling. The

361 valuable knowledge of protecting spruce understory during aspen harvest (MacIsaac and Krygier

362 2009) needs to be incorporated into landscape level planning as well as day-to-day harvesting

363 operations. The economic implications of this novel mixedwood practice need to be evaluated

364 both spatially, in the context of timber supply analysis, and temporally, as projections over mid-

365 term and long-term timeframes.

\section{Conclusions}

Planting spruce under aspen could be a viable approach for a wider range of aspen and

368 understory light conditions than have been initially suggested in the literature. There was a

369 statistically significant growth benefit of approximately $25 \%$ in height and $40 \%$ in diameter,

370 conferred by planting spruce into aspen stands where basal area was reduced by thinning. In

371 addition, spruce in lower basal area aspen stands had lower height/dbh which would make the

372 spruce less susceptible to windthrow after an aspen harvest. Moreover, a lower aspen stem

373 density would contribute to reduced damage to retained spruce when the aspen overstory is

374 removed during understory protection harvesting.

375 The moderated environment under aspen is likely to become increasingly advantageous if

376 more frequent and sustained drought episodes are a critical feature of future climates. 
378 Acknowledgements

379 We gratefully acknowledge funding support provided by the B.C. Ministry of Forests,

380 Land and Natural Resource Operations and the assistance with field data collection provided by

381 contractors and students during the life of this study. We also thank three anonymous reviewers

382 and the Associate Editor for comments that greatly improved the manuscript. 


\section{References}

385

386

387

388

389

390

391

392

393

394

395

396

397

398

399

400

401

402

403

404

405

406

407

408

409

410

411

412

413

414

415

416

417

418

419

420

421

422

423

424

425

426
Bergeron, Y., Chen, H. Y. H., Kenkel, N.C., Leduc, A. L., and Macdonald, S.E. 2014. Boreal mixedwood stand dynamics: Ecological processes underlying multiple pathways. For. Chron. 90 (2):202-213

Brown, S.M., Petrone, R.M., Chasmer, L., Mendoza, C., Lazerjan, M.S., Landhausser, S.M., Silins, U., Leach, J., and Devito, K.J. 2014. Atmospheric and soil moisture controls on evapotranspiration from above and within a Western Boreal Plan aspen forest. Hydrol. Proc. 28(15):4449-4462

Carlson, D.W. and Groot, A. 1997. Microclimate of clear-cut, forest interior and small openings in trembling aspen forest. Agricultural and Forest Meteorology 97:313-329

Chen, J.M, Blanken, P.D., Black, T.A, Guilbeault, M., and Chen, S. 1997. Radiation regime and canopy architecture in a boreal aspen forest. Agric. For. Met. 86: 107-125

Chhin, S. and Wang, G.G. 2008. Climatic response of Picea glauca seedlings in a forest-prairie ecotone of western Canada. Ann. For. Sci. 65(2):207

Comeau, P.G., Filipescu, C.N., Kabzems, R., and DeLong, C. 2004. Early growth of white spruce underplanted beneath spaced and unspaced aspen stands in northeastern B.C. Dan. J. For. Res. 29:1374-1382

Comeau, P.G., Filipescu, C.N., Kabzems, R., and DeLong, C. 2009. Growth of white spruce underplanted beneath spaced and unspaced aspen stands in northeastern B.C. - 10 year results. For. Ecol. Manage. 257:1629-1636

Constabel, A.J. and Lieffers, V.J. 1996. Season patterns of light transmission through boreal mixedwood canopies. Can. J. for. Res. 26: 1008-1014.

de Groot, W. J., Flannigan, M.D. and Cantion, A.S. 2013. Climate change impacts on future boreal fire regimes. For. Ecol. Manage. 294: 35-44

DeLong, C. 2000. Planting white spruce under trembling aspen: 7-year results of seedling condition and performance. Res. Br., B.C. Min. For., Victoria, B.C. Work. Pap 54 (http://www.for.gov.bc.ca/hfd/pubs/Docs/Wp/Wp54.htm)

DeLong, C., Banner, A., MacKenzie, W.H., Rogers, B.J., and Kaytor, B. 2011. A field guide to ecosystem identification for the Boreal White and Black Spruce Zone of British Columbia. B.C. Min. For. Range, For. Sci. Prog., Victoria, B.C. Land Manag. Handb. No. 65. (www.for.gov.bc.ca/hfd/pubs/Docs/Lmh/Lmh65.htm)

Duffy, P.J.B. 1963. Plantations of white spruce under aspen on different soils, Foothills Section, Alberta. Establishment Report. Project A-83. Forestry Canada, Forest Research Laboratory, Calgary, Alberta. $32 \mathrm{p}$

Dyck, J.R. 1994. Converting aspen stands to white spruce-aspen mixedwoods by planting and seeding, Manitoba: Manitoba forestry demonstration areas. Can. For. Serv., NW Reg., Winnipeg, Man.

Gartner, S.M., Lieffers, V.J., and Macdonald S.E. 2011. Ecology and management of natural regeneration of white spruce in the boreal forest. Environ. Rev. 19:461-478

Groot, A. and Carlson, D.W. 1996. Influence of shelter on night temperatures, frost damage, and bud break of white spruce seedlings. Can. J. For. Res. 26: 1531-1538.

Grover, B.E., Bokalo, M., and Greenway, K.J. 2014. White spruce understory protection: from planning to growth and yield. For. Chron. 90:35043 
427

428

429

430

431

432

433

434

435

436

437

438

439

440

441

442

443

444

445

446

447

448

449

450

451

452

453

454

455

456

457

458

459

460

461

462

463

464

465

466

467

468

469

470

471

472

Haughian, S.R., Burton, P.J., Taylor, S.W. and Curry, C.L. 2012. Expected effects of climate change on forest disturbance regimes in British Columbia. BC Jour. Eco. Manage. 13(1):124

Hogg, E.H. 2001. Modeling aspen responses to climatic warming and insect defoliation in western Canada. IN: Sustaining Aspen in Western Landscapes: Symposium Proceedings, 13-15 June, 2000, Grand Junction, CO. W.D. Shepperd, D. Binkley, D.L. Bartos, T.J. Stohlgren, and L.G Eskew (editors). Proceedings RMRS-P-18. USDA Forest Service, Fort Collins, CO. pp. 325-338

Hogg, E.H. and Bernier, P.Y. 2005. Climate change impacts on drought-prone forests in western Canada. For. Chron. 81:675-682

Johnson, H.J. 1986. The release of white spruce from trembling aspen overstorys: a review of available information and silvicultural guidelines. Dep. Nat. Resources, For. Br., Can/Manitoba Econ. Reg. Devel., Winnipeg, Man. Unpublished report.

Johnston, M., Campagna, M, Grapy, P., Kope, H., Loo, J., Ogden, A., O’Neill, G.A., Price, D., and Williamson, T. 2009. Vulnerability of Canada's tree species to climate change and management options for adaptation: An overview for policy makers and practitioners.

Canadian Council of Forest Ministers. http://www.ccfm.org/pdf/TreeSpecies_web_e.pdf

Kabzems, R.D., Harper, G, and Fielder, P. 2011. Growing space management in boreal mixedwood forests: 11-Year results. West. J. Appl. For. 26(2): 83-90

Kemball, K.J., Wang, G.C. and Dang, Q. L. 2005. Response of understory plant community of boreal mixedwood stands to fire, logging, and spruce budworm outbreak. Can. J. Bot. 83: $1550-1560$

LaMalfa, E.M. and Ryle, R. 2008. Differential snowpack accumulation and water dynamics in aspen and conifer communities: implications for water yield and ecosystem function. Ecosystems 11: 569-581

Lanner, R.M. 1985. On the insensitivity of height growth to spacing. For. Eco. Manage. 13(34): $143-148$

Lieffers, V., and Grover, B. 2004. Alternative silviculture for boreal mixedwood forests of Alberta. Sustainable Forest Management Network.

http://www.sfmn.ales.ualberta.ca/Publications/ /media/sfmn/Publications/SynthesisReports/Doc uments/SR_200304lieffersvalte_en.ashx

MacIsaac, D.A. and Krygier, R. 2009. Development and long-term evaluation of harvesting patterns to reduce windthrow risk of understorey spruce in aspen-white spruce mixedwood stands in Alberta, Canada. Forestry 82(3): 323-342

Man, R. and Lieffers, V.J. 1997. Seasonal variations of photosynthetic capacities of white spruce (Picea glauca) and jack pine (Pinus banksiana) saplings. Can. J. Bot. 75:1755-1771

Marsden, B.J., Lieffers, V.J and Zwiazek, J.J. 1996. The effect of humidity on photosynthesis and water relations of white spruce seedlings during the early establishment phase. Can. J. For. Res. 26: 1015-1021

Mbogga, M.S., Wang, X., and Hamann, A. 2010. Bioclimate envelope model predictions for natural resource management: dealing with uncertainty. Jour. Appl. Ecol. 47:731-740

Montgomery, R.A., Reich, P.B., and Palik, B.J. 2010. Untangling positive and negative biotic interactions: views from above and below ground in a forest ecosystem. Ecology 91(12): 3641-3655

Navratil, S. 1996. Silvicultural systems for managing deciduous and mixedwood stands with white spruce understory. In: Silviculture of temperate and boreal broadleaf-conifer 
mixtures. P.G. Comeau and K.D. Thomas, Eds. B.C. Ministry of Forests, Victoria. Pp. 3546

Nlungu-Kweta, P., Leduc, A., and Bergeron, Y. 2014. Conifer recruitment in trembling aspen (Populus tremuloides Michx.) stands along an east-west gradient in the boreal mixedwoods of Canada. Forests 5:2905-2928

O’Hara, K.L. and Ramage, B.S. 2013. Silviculture in an uncertain world: utilizing multi-aged management systems to integrate disturbance. Forestry 86:401-410

Park, A., Puettmann, K., Wilson, E., Messier, C., Kames, S., and Dhar, A. 2014. Can boreal and temperate forest management be adapted to the uncertainties of $21^{\text {st }}$ Century climate change? Crit. Rev. Plant Sci.:33(4):251-285

Pommerening, A. and Murphy, S.T. 2004. A review of the history, definitions and methods of continuous cover forestry with special attention to afforestation and restocking. Forestry 77: 27-44

Prevost, M. and Pothier, D. 2003. Partial cuts in a trembling aspen conifer stand: effects on microenvironmental conditions and regeneration dynamics. Can. J. For. Res. 33(1):1-15

Price, D.T., Alfaro, R.I., Brown, K.J., Flannigan, M.D., Fleming, R.A., Hogg, E.H., Girardin, M.P., Lakusta, T., Johnston, M., McKenney, D.W., Pedlar, J.H., Stratton, T., Sturrock, R.N., Thompson, I.D., Trofymow, J.A., and Venier, L.A. 2013. Anticipating the consequences of climate change for Canada's boreal forest ecosystems. Environ. Rev. 21: 322-365

Pritchard, J.M. and Comeau, P.G. 2004. Effects of opening size and stand characteristics on light transmittance and temperature under young trembling aspen stands. For. Ecol. Manage. 200: $119-128$

Rehfeldt, G.E., Crookston, N.L., Saenz-Romero, C., and Campbell, E.M. 2012. North American vegetation model for land-use planning in a changing climate: a solution to large classification problems. Ecol. Appl. 22(1):119-141

Schneider, R.R., Hamann, A., Farr, D., Wang, X., and Boutin, S. 2009. Potential effects of climate change on ecosystem distribution in Alberta. Can. J. For. Res. 39(5):1001-1010

Stewart, J.D., Landhausser, S.M., Stadt, K.J., and Lieffers, V.J. 2000. Regeneration of white spruce under aspen canopies: seeding, planting and site preparation. West. J. Appl. For. $15: 177-182$

Taylor, S.P., Alfaro, R.I., DeLong, C., and Rankin, L. 1996. The effects of overstory shading on white pine weevil damage to white spruce and its effect on spruce growth rates. Can. J. For. Res. 26: 306-312.

Trottier, G.C. 1981. Beaked hazelnut - a key browse species for moose in the boreal forest region of western Canada. Alces 17:257-281

Waldron, R.M. 1959. Hazel foliage treatments to reduce suppression of white spruce reproduction. Forest Research Division, Technical Note N. 75. Dept. North. Aff. Nat. Res., Ottawa

Wang, T., Campbell, E.M., O’Neill, G.A., and Aitken, S.N. 2012. Projecting future distribution of ecosystem climate niches: Uncertainties and management applications. For. Ecol. Manage. 279:128-140

Wang, Y., Hogg, E.H., Price, D.T., Edwards, J., and Williamson, T. 2014. Past and projected future changes in moisture conditions in the Canadian boreal forest. For. Chron. 2014(5):678-691 
518 Table 1. Summary of spruce survival to 2014, by aspen spacing treatment at the Sierra Road 519 site and year 15 survival at the two Dawson Creek sites.

\begin{tabular}{lc}
\hline $\begin{array}{l}\text { Aspen spacing } \\
\text { treatment }\end{array}$ & $\begin{array}{c}\text { Survival } \\
(\%)\end{array}$ \\
\hline & \\
Control & 95 \\
3000 stems ha $^{-1}$ & 96 \\
2000 stems ha $^{-1}$ & 98 \\
1000 stems ha & \\
Dawson Creek & 99 \\
\hline
\end{tabular}

520

521 
523 Table 2a. Analysis of Variance of planted white spruce diameter, height, and height/dbh in 2014.

\begin{tabular}{|c|c|c|c|c|c|c|c|c|c|}
\hline Effect & \multicolumn{3}{|c|}{ Diameter@1.3 m } & \multicolumn{2}{|c|}{ Height } & \multicolumn{4}{|c|}{ Height/dbh } \\
\hline & $\mathrm{df}$ & $\begin{array}{l}\mathrm{F} \\
\text { Value }\end{array}$ & $\begin{array}{l}\text { Prob } \\
\geq F\end{array}$ & $\mathrm{df}$ & $\begin{array}{l}\text { F } \\
\text { Value }\end{array}$ & $\begin{array}{l}\text { Prob } \\
\geq F\end{array}$ & $\mathrm{df}$ & $\begin{array}{l}\mathrm{F} \\
\text { Value }\end{array}$ & $\begin{array}{l}\text { Prob } \\
\geq F\end{array}$ \\
\hline $\begin{array}{l}\text { Height } \\
1997\end{array}$ & 1 & 42.04 & $<.01$ & 1 & 65.35 & $<.01$ & 1 & 4.24 & 0.06 \\
\hline $\begin{array}{l}\text { Spacing } \\
\text { (S) }\end{array}$ & 3 & 3.72 & 0.02 & 3 & 3.02 & 0.05 & 3 & 3.09 & 0.04 \\
\hline $\begin{array}{l}\text { Fertilizer } \\
\text { (F) }\end{array}$ & 3 & 0.02 & 1.00 & 3 & 0.03 & 0.99 & 3 & 0.85 & 0.48 \\
\hline $\mathrm{S} \times \mathrm{F}$ & 9 & 0.67 & 0.73 & 9 & 0.92 & 0.52 & 9 & 0.54 & 0.84 \\
\hline
\end{tabular}

525 Table 2b. Analysis of Variance of planted white spruce height increment 2002-2014, height 526 increment 2007-2014, and root collar diameter growth 2002-2007.

\begin{tabular}{|c|c|c|c|c|c|c|c|c|c|}
\hline \multirow[t]{2}{*}{ Effect } & \multicolumn{3}{|c|}{$\begin{array}{l}\text { Height increment } \\
\text { 2002-2014 }\end{array}$} & \multicolumn{3}{|c|}{$\begin{array}{l}\text { Height increment } \\
2007-2014 \\
\text { (2007 sub-sample) }\end{array}$} & \multicolumn{3}{|c|}{$\begin{array}{l}\text { Root collar } \\
\text { diameter growth } \\
\text { 2002-2007 } \\
(2007 \text { sub-sample }) \\
\end{array}$} \\
\hline & df & $\begin{array}{l}\text { F } \\
\text { Value }\end{array}$ & $\begin{array}{l}\text { Prob } \\
\geq F\end{array}$ & $\mathrm{df}$ & $\begin{array}{l}\text { F } \\
\text { Value }\end{array}$ & $\begin{array}{l}\text { Prob } \\
\geq \mathrm{F}\end{array}$ & $\mathrm{df}$ & $\begin{array}{l}\text { F } \\
\text { Value }\end{array}$ & $\begin{array}{l}\text { Prob } \\
\geq F\end{array}$ \\
\hline $\begin{array}{l}\text { Height } \\
1997\end{array}$ & 1 & 34.54 & $<.01$ & 1 & 10.37 & $<.01$ & 1 & 13.90 & $<.01$ \\
\hline $\begin{array}{l}\text { Spacing } \\
\text { (S) }\end{array}$ & 3 & 2.18 & 0.11 & 3 & 0.73 & 0.55 & 3 & 3.00 & 0.07 \\
\hline $\begin{array}{l}\text { Fertilizer } \\
\text { (F) }\end{array}$ & 3 & 0.01 & 1.0 & 1 & 0.93 & 0.35 & 1 & 0.40 & 0.53 \\
\hline $\mathrm{S} \times \mathrm{F}$ & 9 & 1.11 & 0.39 & 3 & 0.28 & 0.84 & 3 & 0.69 & 0.57 \\
\hline
\end{tabular}


531 Table 3. Summary of aspen stand mean density and basal area in 1992, 2003 and 2014, by 532 treatment at the Sierra Road site.

\begin{tabular}{lcccccc}
\hline $\begin{array}{l}\text { Aspen spacing } \\
\text { treatment }\end{array}$ & \multicolumn{2}{c}{1992} & \multicolumn{2}{c}{2003} & \multicolumn{2}{c}{2014} \\
\hline & Stems ha & $\begin{array}{c}\text { Basal area } \\
\left(\mathrm{m}^{2} \mathrm{ha}^{-1}\right)\end{array}$ & Stems ha $^{-1}$ & $\begin{array}{c}\text { Basal area } \\
\left(\mathrm{m}^{2} \mathrm{ha}^{-1}\right)\end{array}$ & Stems ha $^{-1}$ & $\begin{array}{c}\text { Basal area }^{2} \\
\left(\mathrm{~m}^{2} \mathrm{ha}^{-1}\right)\end{array}$ \\
\hline Control & 5271 & 35.2 & 3492 & 38.5 & 1952 & 38.9 \\
3000 stems ha $^{-1}$ & 3026 & 27.7 & 2704 & 36.3 & 1839 & 39.8 \\
2000 stems ha $^{-1}$ & 1942 & 19.9 & 1840 & 28.9 & 1523 & 35.6 \\
1000 stems ha $^{-1}$ & 1011 & 12.5 & 960 & 23.1 & 881 & 27.3 \\
\hline
\end{tabular}


Figure 1. Mean spruce height ( + standard error) in 2014 for the aspen thinning treatments at Sierra Road.

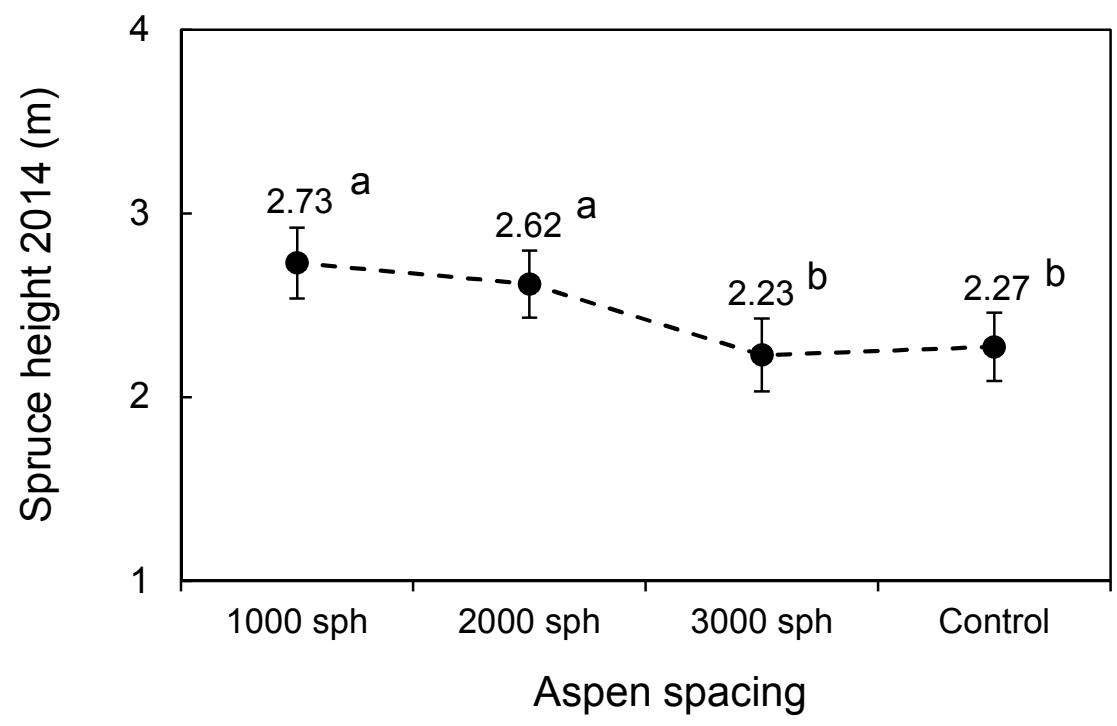

Figure 2. Mean spruce breast height $(1.3 \mathrm{~m})$ diameter ( \pm standard error) in 2014 for the aspen thinning treatments at Sierra Road.

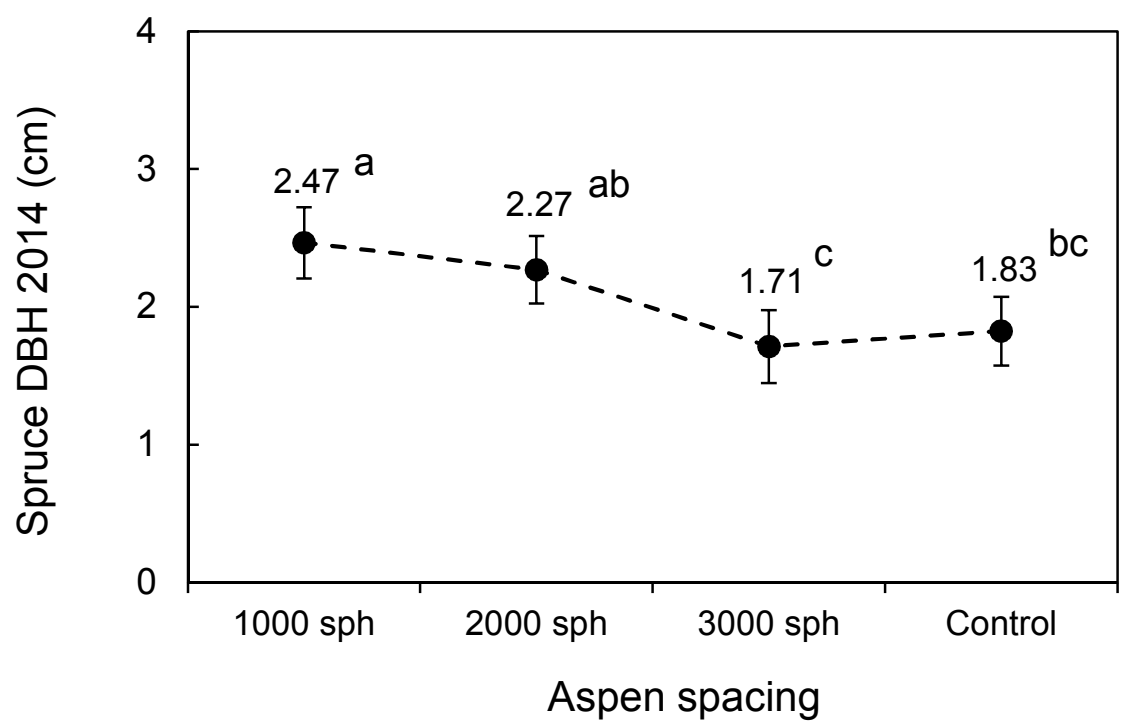


Figure 3. Spruce height/dbh ( + standard error $)$ in 2014 for the aspen thinning treatments at Sierra Road.

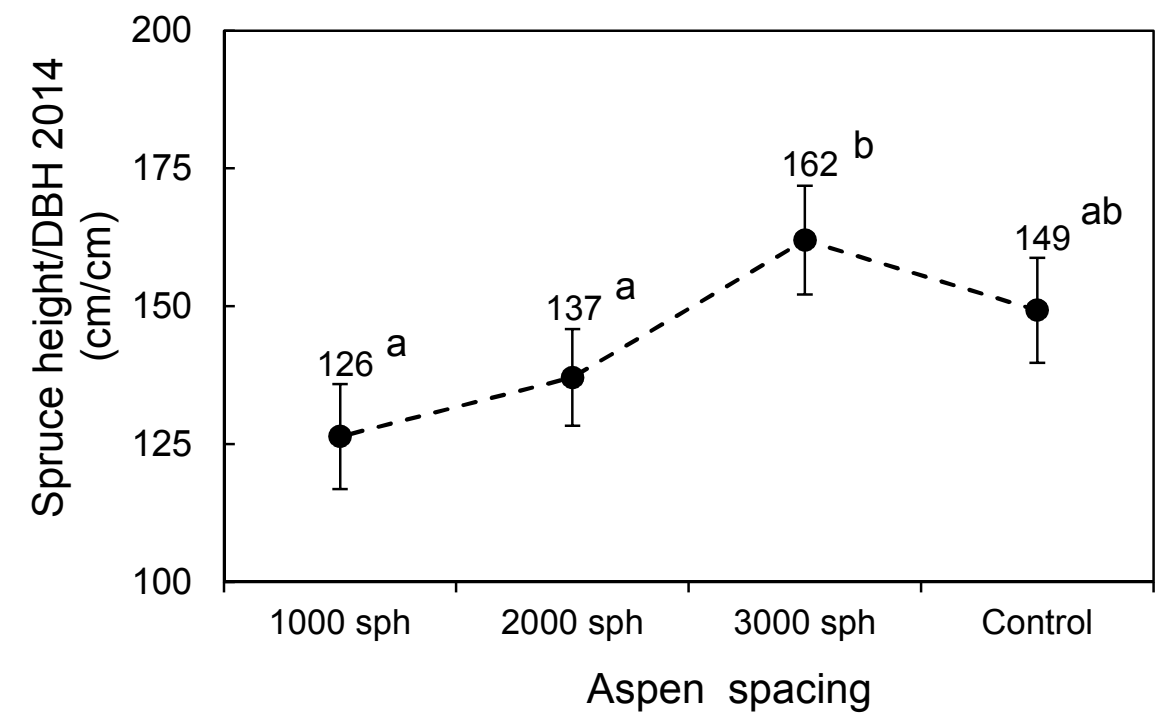

Figure 4. Mean spruce height increment 2002 - 2014 ( \pm standard error) in 2014 for the aspen thinning treatments at Sierra Road.

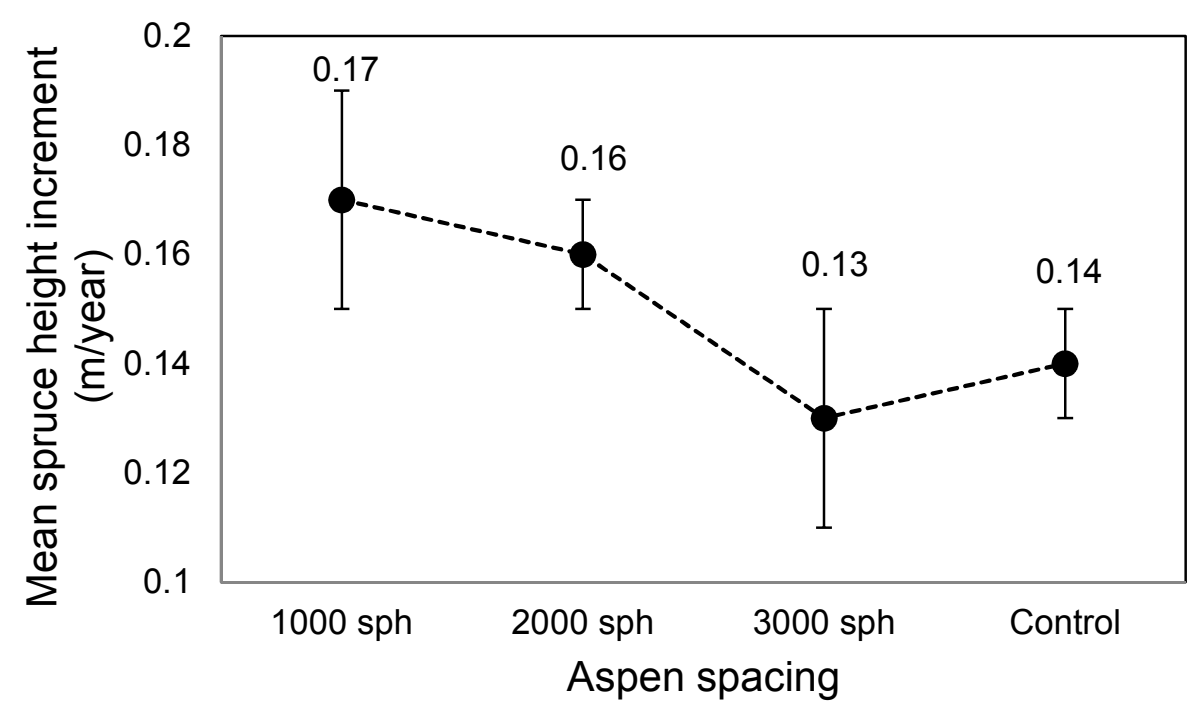


Figure 1. Mean spruce height ( + standard error) in 2014 for the aspen thinning treatments at Sierra Road.

Figure 2. Mean spruce breast height $(1.3 \mathrm{~m})$ diameter ( - standard error) in 2014 for the aspen thinning treatments at Sierra Road.

Figure 3. Spruce height/dbh ( \pm standard error) in 2014 for the aspen thinning treatments at Sierra Road.

Figure 4. Mean spruce height increment 2002 - 2014 ( \pm standard error) in 2014 for the aspen thinning treatments at Sierra Road. 